\title{
Genome group classification and diversity analysis of talas and rutai banana, two local cultivars from East Kalimantan, based on morphological characters
}

\author{
WIDI SUNARYO", AHMAD MULYADI, NURHASANAH \\ Department of Agroecotechnology, Faculty of Agriculture, Mulawarman University. Jl. Pasir Balengkong No.1, Kampus Gunung Kelua, Samarinda \\ 75123, East Kalimantan, Indonesia. Tel.: +62-541-749159, Fax.: +62-541-738341, ’email: widi_sunaryo @ yahoo.com
}

Manuscript received: 4 July 2019. Revision accepted: 27 July 2019.

\begin{abstract}
Sunaryo W, Mulyadi A, Nurhasanah. 2019. Genome group classification and diversity analysis of talas and rutai banana, two local cultivars from East Kalimantan, based on morphological characters. Biodiversitas 20: 2355-2367. Talas and rutai banana are two local cultivars grown in East Kalimantan and long-time used as dessert or cooking bananas for traditional food and cakes, but unfortunately, their taxonomic and genetic status are still little known. This study was conducted to explore their taxonomic and genetic status through morphological observation, genomic group classification and diversity analysis of talas and rutai banana compared to other recognized and identified bananas in Indonesia, i.e., liar/monyet, Ambon, tanduk and klutuk banana. In total 108 morphological characters were observed on site of growing area using the "Descriptors for Banana (Musa spp.)" morphological indicators. The genome group classification was carried out using Simmonds and Shepherd scoring system toward fifteen key banana characters. The diversity analysis was performed using Hierarchy Cluster Analysis at MINITAB 17.1 software based on the selected characters of the highest Principal Component Analysis (PCA) values. The morphological observation showed that the characters of talas and rutai banana are much closely related to those of belonging to $M$. acuminata although some characters showed balbisiana-type. In addition, liar/monyet and klutuk banana morphological characters were exactly matched with the M. acuminata and M. balbisiana accessions. Furthermore, most of Ambon banana morphological characters are similar to M. acuminata, but tanduk banana had a combination characters between $M$. acuminate and $M$. balbisiana. The genome group classification showed that talas and rutai banana are the AAB genotype, while liar/monyet, Ambon, tanduk, and klutuk were grouped into AA, AAA, AB, and BB genotype, respectively. The diversity analysis showed that talas and rutai banana have a very high similarity about $75 \%$ and closed related to AA/AAA genotype i.e., liar/monyet and Ambon with similarities level of $45 \%$.
\end{abstract}

Keywords: Talas and rutai banana, morphological observation, genome classification, diversity analysis, East Kalimantan

\section{INTRODUCTION}

Bananas (Musa paradisiaca), monocotyledons herbs, have played an important role in food supply mainly in tropical and subtropical countries served as dessert or cooking bananas (Lescot 2011). Banana is very good for human diet due to the high nutritional contents such as carbohydrates, vitamins, and minerals (Wall 2006). Furthermore, bananas are affordable fruit and abundantly available in the local or supermarket since they can be cultivated in very broad range of climate and environment condition.

There are around 1940 cultivars of recognized bananas in the world (Crichton et al. 2016). The hybridization and genetic mutation of the diverse species and subspecies have enlarged the genetic diversity of banana cultivars and landraces (Heslop-Harrison and Schwarzacher 2007). The edible bananas are selected for seedless, parthenocarpydeveloped fruit, triploidy genome (Simmonds and Shepherd 1955; Simmonds 1962; Valmayor et al. 2000). The domestication of banana is considered by the economic value of the banana cultivars for food and industries. The modern bananas, referring to the bananas cultivated in the largest area of cultivation for food and industries, are usually derived from the triploid seedless banana as a result of hybridization and genetic improvement of banana ancestor i.e. Musa acuminata (AA genome) and Musa balbisiana (BB genome) (Espino et al. 1992). Those are classified as Eumusa characterized by the chromosome number of $2 \mathrm{n}=2 \mathrm{x}=22$ (Wong et al. 2002). For the triploid seedless bananas, the fruit parthenocarpic development has occurred since there is a failure of fertilization (Horry et al. 1997).

The formation of modern bananas involved their ancestors i.e. $M$. acuminata referred to A-genome, and $M$. balbisiana referred to B-genome. A-genome is characterized by the sweet and dessert banana, whereas, the B-genome is referred for the hardiness and starchiness banana (Pillay et al. 2002). There are specific different morphological characters between both species. Simmonds and Shepherds (1955) used these characters to classify the genome group of their interspecific triploid hybrids such as triploid hybrids of plantains (AAB genotype) and other cooking bananas (ABB genotype). Furthermore, the interspecific hybrids of both species can be referred to as Musa x paradisiaca (Espino et al. 1992).

Indonesia is one of the diversity centers of $M$. acuminata and M. balbisiana species (Purseglove 1985; 
Horry et al. 1997) and there are more than 325 cultivars/clones which 14 of them are domesticated and cultivated for food and small industries by Indonesian people (Setyadjit et al. 2003). The contribution of bananas to Indonesian economy cannot be neglected since bananas is the most important fruit commodity with the highest fruit production of 7,128,698.6 ton in 2017 (Directorate General of Horticulture, Ministry of Agriculture, Republic of Indonesia 2017). Therefore, many efforts have been donated to explore, identify and conserve Indonesian banana germplasms. Many clones commercially cultivated by farmer are still unidentified and recognized including those are existing in Borneo/Kalimantan Island.

Talas and rutai banana, two local cultivar bananas from East Kalimantan, have been cultivated for long years ago, but the taxonomic and genetic status are still unknown. The morphological observation and characterization of talas banana have been reported (Sunaryo et al. 2017), but the same observation has not been performed for the rutai banana. Talas banana is a superior variety showing high agronomic performances, nutritional status and economic value such as high yield and fruit performance at an appropriate cultivation input, good taste, soft texture, sweet, not astringent or sour, high starch content, low water content, and long shelf-life. The fruit is unique and interesting, yellow-orange pulp color and long-curved fruit apex. The high economic value is indicated by the high price in local market (IDR 20,000-40,000 per hand) compared to other commercial bananas (Sunaryo et al. 2017). Based on the initial observation, rutai banana does not possess good agronomic performance since the fruit is tiny, therefore the yield per hectare is very low about 3-5 $\mathrm{kg}$ per bunch. However, the fruit of rutai banana has a unique shape with lengthily pointed apex and curved fruit shape. The nutritional value and the fruit performance have not been studied, but the fruit is very delicious, easily peeled, very sweet and very soft therefore it is preferred by children and old people. The price in the local market is also very high showing good economic value of this cultivar.

Banana genome classification using morphological characters has been widely known (Simmonds and Shepherd 1955; Silayoi and Chomchalow 1987; Pillay et al. 2004). They used 15 remarkable morphological and distinctive characters for taxonomy scoring in genome classification as proposed by Simmonds and Shepherds (1955). This taxonomy scoring method is still reliable and feasible for Musa spp., but it has limitation in the genome determination especially for $M$. Schizocarpa and Australimusa species (Phillay et al. 2004). The genome classification and diversity analysis of Indonesian bananas were reported (Damayanti 2007; Sukartini 2007; Wahyuningtyas et al. 2009; Retnoningsih 2009; Rinaldi et al. 2014; Fitriyah et al. 2017). In the previousgenetic diversity studies, talas and rutai banana were excluded since they were little known and limited grown. This article reported the genome group classification and diversity analysis of talas and RUTAI banana, two local cultivars from East Kalimantan, based on morphological characters.

\section{MATERIALS AND METHODS}

\section{Plant materials}

Two local cultivars from East Kalimantan (talas and rutai bananas), and four other cultivars i.e. Ambon (Genome AAA), tanduk (ABB), liar/monyet (AA) and klutuk (BB) were used in this research. Liar/monyet and Kluthuk bananas was used in this study since they are known and identified as diploid Musa acuminata and Musa balbisiana cultivars and the ancestor of modern bananas (Simmonds and Sheperd 1955). These cultivars were used as genome group control for the banana target identification according to Simmonds and Shepherd genome classification system. The Ambon and tanduk bananas were used in this study to represent the cultivar possessing A and B genome. All banana trees from the 6 cultivars were observed on-site by field visit to the determined grown area (local farmer field) located at Kutai Kertanegara, Paser and Samarinda districts, East Kalimantan Province, Indonesia.

\section{Plant morphological observation}

The morphological characters were observed for plant identification based on the criteria of plant and fruit morphological characters in the "Descriptors for Banana (Musa spp.)" (INIBAB 1996). The flower morphology was specifically analyzed to observe the morphology of male and female flower organ determining the normal or abnormality of the flower and the male or female sterility. The normal or abnormality of banana flower will show the fruit seed identity and possibly will also represent the ploidy of the banana genome. The mature banana flowers were collected from the fresh banana male buds. The bracts of male bud were opened and sectioned, thereafter, separated from the male bud to obtain the fresh mature intact flowers. The whole plant and specific organ pictures such as leaves, pseudostem, male bud, suckers, bunch, flower and fruit were taken using a Nikon Camera.

\section{Genome group classification}

The classical genome group classification was employed as described by Simmonds and shepherd (1955) and updated by Stover and Simmonds (1987). Besides the Simmonds and Shepherd scoring system, the other system as described by Silayoi and Chamchalow (1987), Singh et al. (2014), and Rinaldi et al. (2014) were also used. The score of fifteen banana key characters was recorded and inputted in the scoring tables. The fifteen characters as described by Simmonds and Shepherd system are the key characters of two ancestors of modern banana i.e. $M$. acuminata and $M$. balbisiana (Table 1). Each banana cultivar will be scored as 1, 2, 3, 4 and 5, based on their morphological characters. The score 1 is for the cultivar similar to/or has high similarity to $M$. acuminata whereas score 5 is for those similar to/or has high similarity to $M$. balbisiana. Score 2-4 is the intermediate score determined by identifying the similarity level of the samples to $M$. acuminata or M. balbisiana. The total score of each banana variety, thereafter, was compared to the genome score indication as described in Table 2. 
Table 1. Fifteen key characters of Musa acuminate and Musa balbisiana according to Simmonds and Shepherd's (1985)

\begin{tabular}{|c|c|c|c|}
\hline No & Character & Musa acuminata & Musa balbisiana \\
\hline 1 & Pseudostem color & $\begin{array}{l}\text { More or less heavily marked with brown or } \\
\text { black blotches }\end{array}$ & Blotches very slight or absent \\
\hline 2 & Petiole canal & $\begin{array}{l}\text { Margin erect or spreading, with scarious wings } \\
\text { below, not clasping pseudostem }\end{array}$ & $\begin{array}{l}\text { Margin inclosed, not winged but clasping } \\
\text { pseudostem }\end{array}$ \\
\hline 3 & Peduncle & Usually downy or hairy & Glabrous \\
\hline 4 & Pedicels & Short & Long \\
\hline 5 & Ovules & Two regular rows in each loculus & Four irregular rows in each loculus \\
\hline 6 & Bract shoulder & Usually high $($ ratio< $<0.28)$ & Usually low (ratio $>0.30$ ) \\
\hline 7 & Bract curling & Bracts reflex and rollback after opening & Bracts do not reflex \\
\hline 8 & Bract shape & $\begin{array}{l}\text { Lanceolate or narrowly ovate, tapering sharply } \\
\text { from the shoulder }\end{array}$ & Broadly ovate, not tapering sharply \\
\hline 9 & Bract apex & Acute & Obtuse \\
\hline 10 & Bract color & $\begin{array}{l}\text { Red, dull purple or yellow outside; pink, dull } \\
\text { purple or yellow inside }\end{array}$ & $\begin{array}{l}\text { Distinctive brownish-purple outside; bright } \\
\text { crimson inside }\end{array}$ \\
\hline 11 & Color fading & $\begin{array}{l}\text { Inside bract color usually fades to yellow } \\
\text { towards the base }\end{array}$ & Inside bract color usually continuous to base \\
\hline 12 & Bract scars & Prominent & Scarcely prominent \\
\hline 13 & Free tepal of male flower & Variably corrugated below tip & Rarely corrugated \\
\hline 14 & Male flower color & Creamy white & Variably flushed with pink \\
\hline 15 & Stigma color & Orange or rich yellow & Cream, pale yellow or pale pink \\
\hline
\end{tabular}

Table 2. Determinant scoring of genome group classification based on the morphological characters in banana (Table was adopted from Singh et al. (2014) and Rinaldi et al. (2014)

\begin{tabular}{lcccc}
\hline $\begin{array}{l}\text { Genome } \\
\text { group }\end{array}$ & $\begin{array}{c}\text { Simmonds } \\
\text { and } \\
\text { Shepherd } \\
(\mathbf{1 9 8 2})\end{array}$ & $\begin{array}{c}\text { Silayoi and } \\
\text { Chamchalow } \\
(\mathbf{1 9 8 7})\end{array}$ & $\begin{array}{c}\text { Singh et } \\
\text { al. } \\
\mathbf{( 2 0 1 4 )}\end{array}$ & $\begin{array}{c}\text { Rinaldi } \\
\text { et al . } \\
\mathbf{( 2 0 1 4 )}\end{array}$ \\
\hline AA/AAA & $15-23$ & $15-27$ & $15-25$ & $15-25$ \\
AAB & $24-46$ & $26-46$ & $26-45$ & $26-46$ \\
AB & 49 & - & $46-49$ & $47-58$ \\
ABB & $59-63$ & $59-63$ & $59-65$ & $59-63$ \\
ABBB & 67 & - & $66-69$ & $64-75$ \\
BB/BBB & - & $70-75$ & $70-75$ & - \\
\hline
\end{tabular}

\section{Data analysis}

The plant diversity was analyzed using 108 morphological characters adopted from the banana descriptor (INIBAB 1996). The diversity analysis was performed using the Hierarchy Cluster analysis at Average Linkage (between groups) at MINITAB 17.1 software to obtain the similarity level and the genetic relationships among varieties showing by a dendrogram. The dendrogram will show the genetic relationships and distance among groups and accessions. The raw data for the diversity analysis were obtained from the conversion of morphological characters by Principal Component Analysis $(P C A)$ and thereafter they were selected for only the characters producing the PCA values more than 0.750 . The higher PCA value the higher level of characters to discriminate the accessions differences.

\section{RESULTS AND DISCUSSION}

\section{Plant morphology}

Liar/monyet and klutuk banana were used in this study suggested as representatives of $M$. acuminata and $M$. balbisiana respectively, the ancestors of modern banana (Simmonds and Sheperd 1955; D'Hont et al. 2012), as control of banana identification and characterization. Liar/monyet banana has been identified as a $M$. acuminata species (Retnoningsih 2009; 2014) with AA genome (sweet banana), whereas klutuk is characterized as M. balbisiana cultivar with BB genome or referred to cooking banana (Sumardi and Wulandari 2010; Retnoningsih et al. 2014; Fitriyah et al. 2017).

The morphological observation of liar/monyet banana resulted in the unsurprisingly similar indication as a $M$. acuminata showing remarkably characters such as dark brown blotches in pseudostem, U-shaped canal petiole, very hairy peduncle, very short pedicels, the reflexed bracts after opening, lanceolate bract shape, acute bract apex, very prominent bract scars, two irregular rows of ovules in each loculus, horizontal rachis position, and red fading to yellow internal bract color (Table 3, Figure 1.A). In addition, liar/monyet banana is an inedible banana, because it contains very dense seeds in fruit aril indicating a diploid AA genome of $M$. acuminata species. These results indicate that liar/monyet banana can be used as representative of $M$. acuminata in this study since it shows a true $M$. acuminata characters.

The observation of klutuk banana showed remarkably M. balbisiana properties as reported by Simmonds and Sheperd (1955) such as very few blotches on the pseudostem, inward margin of the petiole canal, glabrous peduncle, long pedicels, four irregular rows of ovules, unreflexed bracts before falling, broadly ovate bract shape, obtuse bract apex, scarcely prominent bract scars, bright crimson color in internal bract, and vertically rachis position (Table 3, Figure 1.B). The seeds composing of klutuk banana fruit indicates that this cultivar is a diploid BB genome of $M$. balbisiana. These indicate that klutuk banana used in this study is a true M. balbisiana and can be 
used as representative of this accession. Other report showed that there is another "klutuk" called as "klutuk susu" but it had AAB genome with some character differences compared to M. balbisiana characters (Fitriyah et al. 2017).

Morphological observation of talas and rutai banana showed a combined character derived from the banana ancestors i.e. Musa acuminata (Genome AA) and Musa balbisiana (Genome BB). As reported by Simmonds and Shepherd (1955), both banana ancestors have inherited many modern bananas, including talas and rutai banana, via natural or artificial hybridizations, genetic mutation and genetic improvement (Espino et al. 1992; Dolezel et al. 1994). The morphological characterization showed that talas banana has remarkable characters similar to those of belonging to $M$. acuminata such as brown or black blotches in pseudostem, U-shaped margin canal petiole (straight with erect margins), hairy peduncle, the reflexed bracts before falling, lanceolate/ovate bract shape, pointed bract apex, prominent bract scars, and creamy white of male flower color (Table 3, Figure 1.C.). Whereas, some characters are dominantly derived from the M. balbisiana ancestor such as slightly angled hanging bunch, short peduncle with the length less than $30 \mathrm{~cm}$, vertically falling rachis, medium crimson bright color at internal bract, curved fruit shape with lengthily pointed long fruit apex like a plantain, long pedicle, unfused pedicels that can be separated easily, difficult peeled-fruit, persistent fruit at the pedicle, and vertically rachis and bunch position (Table 3, Figure 1.C). Other specific interesting properties are that talas banana is classified as a medium-size banana (2.1$2.9 \mathrm{~m}$ ) with a slimy pseudostem, and medium plant height (pseudostem height) between 2-3 m (not giant or dwarf banana) (Table 3, Figure 1.C). Most cultivated bananas have pseudostem height in the range of 2-9 m (INIBAB 2000). The bunch is hanging slightly angled on the pseudostem and classified as a medium-size bunch. These results confirm the previous morphological observation as reported by Sunaryo et al (2017). Furthermore, Sunaryo et al (2017) reported that the mature fruit of talas banana showed seedless, soft texture, sweet and tasty properties with medium fruit aril hardness, therefore, it can be used as dessert or cooking banana. These properties are supported by the high content of starch (carbohydrates) in the fruit aril.

Rutai banana is an endemic local banana originated from East Kalimantan classified as dwarf or tiny edible banana with very short pseudostem height $(<2 \mathrm{~m})$ and very slimy pseudostem diameter (Table 3, Figure 1.D). The mature fruit is sweet, soft, tasty, and delicious with the size as big as human fingers, therefore the bunch weight was very low $(<5 \mathrm{~kg})$. The pseudostem of rutai banana is scarcely blotched with red-purple indicates rutai banana has intermediate pseudostem character between $M$. acuminata and M. balbisiana. Among banana characters, the morphology of pseudostem is broadly varied both in length and color (Pillay and Tripathi 2007). Furthermore, the key characters such as petiole canal shape, peduncle surface, bract color and scars, bract shape and apex, ovule arrangement, bract curling, horizontal rachis, and bunch position and flower and stigma color were similar to the $M$. acuminata characters (Table 3, Figure 1.D). The other interesting properties are long fruit pedicels, lengthily pointed fruit apex, curved fruit, easily peeled fruit, and easily fruit fall from hands (deciduous). The mature fruit appeared very bright yellow. This observation indicates that some morphological characters of rutai banana belong to $M$. balbisiana. It can be concluded that the morphological characters of rutai banana are intermediate characters between $M$. acuminata and M. balbisiana, but generally, it is closer to M. acuminata.

Ambon and tanduk banana are broadly and well known among Indonesian commercial bananas. Ambon is the representative of dessert banana and identified as AAA genome banana (Retnoningsih 2009; Retnoningsih et al. 2014; Rinaldi et al. 2014). On the other hand, tanduk banana is a plantain or cooking banana that has been broadly used as foods and cakes. It is reported as AAB genome (Retnoningsih et al. 2014). The morphological observation showed that Ambon banana is a medium-size banana with pseudostem height ranged from 3.0 to $4.0 \mathrm{~m}$ (Table 3, Figure 1.E). The pseudostem is green yellowish colored with dark-brown blotches. Most key characters of Ambon banana observed showed a very close of those belonged to M. acuminata characters (Table 1, Figure 1.E) such as the U-shaped petiole canal, dark brown blotches, reflexed bracts before falling, two rows ovule arrangement, very short pedicels, stopped fruit apex, very prominent bract scars, lanceolate bract shape, pointed/acute bract apex, purple to yellow bract color, and yellow male flower and stigma (Table 3, Figure 1.E). The other prominent character of Ambon banana is the bunch hanging vertically composed of dense fruit and hand. The fruit is soft, easily peeled, and seedless. The mature fruit peel is green (or green yellowish depending on the variety). Ambon banana is very commonly used as dessert/sweet banana.

tanduk banana is well known due to the giant/big fruit size (25-35 cm fruit length and 6-8 cm fruit diameter). In other Indonesian areas, it is called as Agung or Byar banana. The prominent morphological characters of tanduk banana, beside the size, are the outward curved fruit shape that is uncommon/abnormal for banana character (Table 3, Figure 1.F). The other interesting properties are the low number of hands composed about 2-5 hands of the bunch. The fruit has long shelf life; therefore it is appropriate as cooking banana. As a plantain, tanduk banana shows the hard texture of fruit aril even in mature fruit indicating high content of carbohydrates. The pseudostem of tanduk banana is slimy medium size with dark green yellowish color containing very few blotches, which is an intermediate character of pseudostem color between $M$. acuminata and M. balbisiana. The peduncle is glabrous and the bract scars are not prominent (Table 3, Figure 1.F). The fruit is seedless and emerging from the lanceolate male bud. The male bud is composed of fractured lanceolate bracts. The bracts are very slightly reflexed. These indicate that there are some tanduk characters derived from $M$. balbisiana. 
Table 3. Morphological characters of talas and rutai banana compared to other four local cultivars from East Kalimantan based on the Banana Descriptor (INIBAB 1996)

\begin{tabular}{|c|c|c|c|c|c|c|}
\hline \multirow{2}{*}{ Character } & \multicolumn{6}{|c|}{ Banana cultivar } \\
\hline & Talas/sunking & Rutai & Tanduk & Ambon & Liar/monyet & Klutuk \\
\hline Leaf habit & Intermediate & Erect & Intermediate & Intermediate & Erect & Intermediate \\
\hline Dwarfism & Normal & dwarf & Normal & Normal & Normal & Normal \\
\hline Pesudostem height (m) & $2.1-2.9$ & $1.5-2.5$ & $2.5-3.4$ & $3.0-4.0$ & $>3$ & $>3$ \\
\hline Pesudostem aspect & Slender & Slender & Slender & Normal & Slender & Robust \\
\hline Pseudostem color & Green dark brown & Red-purple & Green-yellow & Green dark-brown & Green dark brown & Dark Green \\
\hline Peudostem appearance & Shiny & Shiny & Dull & Dull & Shiny & Dull \\
\hline Pseudostem predominant color & Green & Pink-purple & Light green & Light green & Watery green & Green \\
\hline Pigmentation underlying pseudostem & Red & Pink-purple & Purple & Yellow-Purple & Pink-purple & Green-purple \\
\hline Sap color & Watery & Watery & Watery & Milky & Watery & Milky \\
\hline Wax on leaf sheaths & Moderately waxy & Moderately waxy & Very few wax & Moderately waxy & Very little & Very waxy \\
\hline Development of suckers & $\begin{array}{l}\text { Between } 1 / 4 \text { and } 3 / 4 \text { of the } \\
\text { height of the parent plan }\end{array}$ & $\begin{array}{l}\text { Between } 1 / 4 \text { and } 3 / 4 \text { of the } \\
\text { height of the parent plan }\end{array}$ & $\begin{array}{l}\text { Between } 1 / 4 \text { and } 3 / 4 \text { of } \\
\text { the height of the parent } \\
\text { plant }\end{array}$ & $\begin{array}{l}\text { More than } 3 / 4 \text { of the } \\
\text { height of the parent } \\
\text { plant }\end{array}$ & $\begin{array}{l}\text { More than } 3 / 4 \text { of the } \\
\text { height of the parent } \\
\text { plant }\end{array}$ & $\begin{array}{l}\text { Between } 1 / 4 \text { and } 3 / 4 \text { of the } \\
\text { height of the parent plan }\end{array}$ \\
\hline Sucker position & $\begin{array}{l}\text { Close the parent } \\
\text { (vertical growt) }\end{array}$ & $\begin{array}{l}\text { Close the parent (vertical } \\
\text { growt) }\end{array}$ & $\begin{array}{l}\text { Close the parent } \\
\text { (vertical growt) }\end{array}$ & $\begin{array}{l}\text { Close the parent } \\
\text { (vertical growt) }\end{array}$ & $\begin{array}{l}\text { Close the parent } \\
\text { (vertical growt) }\end{array}$ & $\begin{array}{l}\text { Close the parent } \\
\text { (vertical growt) }\end{array}$ \\
\hline Blotches at the petiole base & Small blotching & Small blotching & Sparse blotching & Sparse blotching & Large Blotches & Sparse blotching \\
\hline Blotches color & Black purple & Brown-black & Dark Brown & Brown-black & Brown-black & Green-black \\
\hline Petiole canal leaf III & $\begin{array}{l}\text { Straight with erect } \\
\text { margins }\end{array}$ & $\begin{array}{l}\text { Straight with erect } \\
\text { margins }\end{array}$ & Margins curved inward & $\begin{array}{l}\text { Straight with erect } \\
\text { margins }\end{array}$ & $\begin{array}{l}\text { Straight with erect } \\
\text { margins }\end{array}$ & Margins curved inward \\
\hline Petiole margins & $\begin{array}{l}\text { Winged and not clasping } \\
\text { the pseudostem }\end{array}$ & $\begin{array}{l}\text { Winged and not clasping } \\
\text { the pseudostem }\end{array}$ & Winged and undulating & $\begin{array}{l}\text { Winged and not clasping } \\
\text { the pseudostem }\end{array}$ & $\begin{array}{l}\text { Winged and not clasping } \\
\text { the pseudostem }\end{array}$ & $\begin{array}{l}\text { Not winged and clasping } \\
\text { the pseudostem }\end{array}$ \\
\hline Wing type & Not dry & Dry & Dry & Dry & Not dry & Dry \\
\hline Petiole margin color & Pink-purple to red & Pink-purple to red & Pink-purple to red & Pink-purple to red & Pink-purple to red & Green \\
\hline Edge of petiole margin & With a color line along & With a color line along & With a color line along & With a color line along & With a color line along & Colorless \\
\hline Petiole margin width & $\leq 1 \mathrm{~cm}$ & $\leq 1 \mathrm{~cm}$ & $>1 \mathrm{~cm}$ & $\leq 1 \mathrm{~cm}$ & $>1 \mathrm{~cm}$ & $\leq 1 \mathrm{~cm}$ \\
\hline Leaf blade length $(\mathrm{cm})$ & $221-260 \mathrm{~cm}$ & $\leq 170 \mathrm{~cm}$ & $\leq 170 \mathrm{~cm}$ & $171-220 \mathrm{~cm}$ & $221-260 \mathrm{~cm}$ & $>261 \mathrm{~cm}$ \\
\hline Leaf blade width $(\mathrm{cm})$ & $\leq 70 \mathrm{~cm}$ & $\leq 70 \mathrm{~cm}$ & $\leq 70 \mathrm{~cm}$ & $71 \mathrm{~s} . \mathrm{d} 80 \mathrm{~cm}$ & $\leq 70 \mathrm{~cm}$ & $81 \mathrm{~s} . \mathrm{d} 90 \mathrm{~cm}$ \\
\hline Petiole length & $51-70 \mathrm{~cm}$ & $\leq 50 \mathrm{~cm}$ & $51-70 \mathrm{~cm}$ & $\leq 50 \mathrm{~cm}$ & $51-70 \mathrm{~cm}$ & $\leq 50 \mathrm{~cm}$ \\
\hline Color of leaf upper surface & Green & $\begin{array}{l}\text { Dark green with red } \\
\text { purple }\end{array}$ & $\begin{array}{l}\text { Dark green with red } \\
\text { purple }\end{array}$ & $\begin{array}{l}\text { Dark green with red } \\
\text { purple }\end{array}$ & $\begin{array}{l}\text { Dark green with red } \\
\text { purple }\end{array}$ & Dark green \\
\hline Appearance of leaf upper surface & Dull & Dull & Shiny & Dull & Shiny & Dull \\
\hline Color of leaf lower surface & Green yellow & Green & Green & Medium green & Green & Dark green \\
\hline Appearance of leaf lower surface & Dull & Dull & Shiny & Dull & Shiny & Dull \\
\hline Wax on leaves & Few waxy & Moderately wax & Moderately wax & Few waxy & Few waxy & Very waxy \\
\hline Insertion point of leaf blades on petiole & Asymetric & Asymetric & Asymetric & Symetric & Asymetric & Simetric \\
\hline Shape of leaf blade base & Both side pointed & Both side pointed & Both side rounded & $\begin{array}{l}\text { One side rounded, one } \\
\text { pointed }\end{array}$ & $\begin{array}{l}\text { One side rounded, one } \\
\text { pointed }\end{array}$ & Both side rounded \\
\hline Leaf corrugation & Even, smooth & Few s & Very corrugated & Few stripes & Even, smooth & Very corrugated \\
\hline Color of midrib dorsal s & Light green & Pink-pr & Pink-purple & Light green & Light green & Green \\
\hline Color of midrib ventral surface & Light green & Pink-purple & Pink-purple & Light green & Light green & Green \\
\hline
\end{tabular}




\begin{tabular}{|c|c|c|c|c|c|c|}
\hline Color of cigar leaf dorsal surface & Green & Red-purple & Red-purple & Green & Red-purple & Green \\
\hline Blotches on leaves of water sucker & Little or narrow blotches & Little or narrow blotches & $\begin{array}{l}\text { Little or narrow } \\
\text { blotches }\end{array}$ & Little or narrow blotches & Large purple blotches & Without blotches \\
\hline Peduncle length $(\mathrm{cm})$ & $\geq 21 \mathrm{~cm}$ (long) & $11-20 \mathrm{~cm}$ (medium long) & $\geq 21 \mathrm{~cm}$ (long) & $\leq 10 \mathrm{~cm}$ (short) & $\leq 10 \mathrm{~cm}$ (short) & $\geq 21 \mathrm{~cm}$ (long) \\
\hline Peduncle width $(\mathrm{cm})$ & $\leq 6 \mathrm{~cm}$ & $6-12 \mathrm{~cm}$ & $>13 \mathrm{~cm}$ & $>13 \mathrm{~cm}$ & $6-12 \mathrm{~cm}$ & $>13 \mathrm{~cm}$ \\
\hline Peduncle color & Dark green & Dark green & Dark green & Dark green & Dark green & Green \\
\hline Peduncle hairiness & Slightly hairy & Slightly hairy & Hairless & Slightly hairy & Very hairy & Hairless \\
\hline Bunch position & Slightly angle & Horizontal & Hanging Vertically & Slightly angle & Slightly angle & Horizontal \\
\hline Bunch shape & Spiral & Spiral & Truncated cone shape & cylindrical & Spiral & Asymetric \\
\hline Bunch appearance & Compact & Compact & Lax & Compact & Compact & Very compact \\
\hline Flowers that form fruits & $\begin{array}{l}\text { Female (absence of } \\
\text { pollen sacs or pollens) }\end{array}$ & $\begin{array}{l}\text { Female (absence off } \\
\text { pollen sacs or pollens) }\end{array}$ & $\begin{array}{l}\text { Female (absence of } \\
\text { pollen sacs or pollens) }\end{array}$ & $\begin{array}{l}\text { Female (absence of } \\
\text { pollen sacs or pollens) }\end{array}$ & $\begin{array}{l}\text { Hermaphrodite } \\
\text { (presence of pollen sacs } \\
\text { or pollens) }\end{array}$ & $\begin{array}{l}\text { Hermaphrodite } \\
\text { (presence of pollen sacs } \\
\text { or pollens) }\end{array}$ \\
\hline Male flower color & Cream & Yellow & Cream & Yellow & Cream & Yellow \\
\hline Positioning of fruits on the crown & Uniseriate & Biseriate dan fused & Biseriate & Biseriate & Biseriate & Uniseriate \\
\hline Rachis type & $\begin{array}{l}\text { Present and male bud } \\
\text { may be degenerated or } \\
\text { persistent }\end{array}$ & $\begin{array}{l}\text { Present and male bud } \\
\text { may be degenerated or } \\
\text { persistent }\end{array}$ & $\begin{array}{l}\text { Truncated, no bract } \\
\text { scar below the last } \\
\text { hand of fruit }\end{array}$ & $\begin{array}{l}\text { Present and male bud } \\
\text { may be degenerated or } \\
\text { persistent }\end{array}$ & $\begin{array}{l}\text { Present and male bud } \\
\text { may be degenerated or } \\
\text { persistent }\end{array}$ & $\begin{array}{l}\text { Present and male bud } \\
\text { may be degenerated or } \\
\text { persistent }\end{array}$ \\
\hline Rachis position & Falling verticaly & Horizontal & At an angle & With a curved & Horizontal & Falling verticaly \\
\hline Male bud type & Present & Present & Absent & Present & Present & Present \\
\hline Male bud shape & Intermediate & Like a top & Fractured & Intermediate & Like a top & Ovoid \\
\hline Male bud size & $21-30 \mathrm{~cm}$ & $\leq 20 \mathrm{~cm}$ & $\geq 31 \mathrm{~cm}$ & $\geq 31 \mathrm{~cm}$ & $\leq 20 \mathrm{~cm}$ & $21-30 \mathrm{~cm}$ \\
\hline Bract base shape/shoulder & Medium & High & High & High & High & Low \\
\hline Bract apex shape & Medium acute & Acute & Acute & Acute & Acute & Obtuse \\
\hline Bract imbrication & $\begin{array}{l}\text { Young bractea greatly } \\
\text { overlap }\end{array}$ & $\begin{array}{l}\text { Young bractea slightly } \\
\text { overlap }\end{array}$ & $\begin{array}{l}\text { Young bractea greatly } \\
\text { overlap }\end{array}$ & $\begin{array}{l}\text { Old bractea overlap at } \\
\text { apex of bud }\end{array}$ & $\begin{array}{l}\text { Old bractea overlap at } \\
\text { apex of bud }\end{array}$ & $\begin{array}{l}\text { Young bractea slightly } \\
\text { overlap }\end{array}$ \\
\hline Color of the bract external face & Dark purple & Dark purple-yellow & Dark purple & Dark purple-yellow & Dark purple-yellow & $\begin{array}{l}\text { Dark purple-bright } \\
\text { crimpson }\end{array}$ \\
\hline Color of the bract internal face & Bright crimpson-yellow & Purple-yellow & $\begin{array}{l}\text { Bright crimpson- } \\
\text { yellow }\end{array}$ & Purple-yellow & Cream-yellow & bright crimpson \\
\hline Color on the bract apex & Discolored & Discolored & Discolored & Discolored & Discolored & $\begin{array}{l}\text { Color is uniform until } \\
\text { apex }\end{array}$ \\
\hline es on bract & With Discolored lines & discolored lines & colored lines & ored lines & red lines & Without discolored lines \\
\hline Bract scars on rachis & Very prominent & Very prominent & Not prominent & Very prominent & Very prominent & Not prominent \\
\hline Fading of color on bract base & Red fades to yellow & Red fades to yellow & Red fades to yellow & Red fades to yellow & Red fades to yellow & Continuosly red \\
\hline Male bract shape & $\begin{array}{l}0.28<\mathrm{x} / \mathrm{y}<0,30 \\
\text { (medium ovate) }\end{array}$ & $\begin{array}{l}\mathrm{x} / \mathrm{y}<0.28 \text { (narrowly } \\
\text { ovate/lanceolate) }\end{array}$ & $\begin{array}{l}\mathrm{x} / \mathrm{y}<0.28 \text { (narrowly } \\
\text { ovate/lanceolate) }\end{array}$ & $\begin{array}{l}\mathrm{x} / \mathrm{y}<0.28 \text { (narrowly } \\
\text { ovate/lanceolate) }\end{array}$ & $\begin{array}{l}\mathrm{x} / \mathrm{y}<0.28 \text { (narrowly } \\
\text { ovate/lanceolate) }\end{array}$ & $\begin{array}{l}x / y>0.30 \text { (broadly } \\
\text { ovate ovate) }\end{array}$ \\
\hline Male bract lifting & $\begin{array}{l}\text { Lifting two or more at a } \\
\text { time }\end{array}$ & Lifting one time at a time & $\begin{array}{l}\text { Lifting one time at a } \\
\text { time }\end{array}$ & $\begin{array}{l}\text { Lifting one time at a } \\
\text { time }\end{array}$ & $\begin{array}{l}\text { Lifting one time at a } \\
\text { time }\end{array}$ & $\begin{array}{l}\text { Lifting two or more at a } \\
\text { time }\end{array}$ \\
\hline Bract behaviour before falling & Bracts reflex & Brac & Bracts do not reflex & Bracts reflex & Bracts reflex & Bracts do not reflex \\
\hline Wax on the bract & Moderately waxy & Few waxy & Moderately waxy & $\begin{array}{l}\text { Very little or visible sign } \\
\text { of wax }\end{array}$ & $\begin{array}{l}\text { Very little or visible sign } \\
\text { of wax }\end{array}$ & Very waxy \\
\hline Presence of grooves on the bract & Moderately grooved & Few grooved & Strongly grooved & Moderately grooved & Few grooved & Strongly grooved \\
\hline Male flower behaviour & Falling after the bract & Falling after the bract & - & Falling after the bract & Falling after the bract & Falling before the bract \\
\hline Compound tepal basic color & Cream & Yellow & Yellow & Yellow & Cream & Yellow \\
\hline Compound tepal pigmentation & $\begin{array}{l}\text { Very few or visible sign } \\
\text { of pigmentation }\end{array}$ & $\begin{array}{l}\text { Very few or visible sign } \\
\text { of pigmentation }\end{array}$ & Rust-colored spot & $\begin{array}{l}\text { Very few or visible sign } \\
\text { of pigmentation }\end{array}$ & $\begin{array}{l}\text { Very few or visible sign } \\
\text { of pigmentation }\end{array}$ & Presence of pink \\
\hline Lobe color of compound tepal & Yellow & Yellow & Yellow & Yellow & Cream & Yellow \\
\hline
\end{tabular}


Little or visible of

development

Free tepal color

Free tepal shape

Free tepal appearance

Free tepal apex development

Free tepal apex shape

Filament color

Anther color

Polen sac color

Style Basic color

Pigmentation on style

Style shape

Stigma Color

Ovary shape

Ovary Basic Color

Ovary pigmentation

Arrangement of ovules

Fruit position

Number of fruit

Fruit length

Fruit shape

Transverse section of fruit

Fruit apex

Tinted with Yellow

Rounded

Tinted with Yellow

Fan-shaped

Developed

Corrugated below the tip Corrugated below the tip

Opaque white

Rounded

development

Transculent white

Rounded

Developed

Opaque white

Rounded

Very development Developed

Triangular

White

Cream

Brown

White

No pigmentation

riangular

Straight

Cream

Arched

Green

Triangula

White

brown

No pigmentation

Curved at the base

Yellow

Arched

Two rowed

Curved upward

13-16

$16-20 \mathrm{~cm}$

Curved

Rounded

Lengthily pointed

Remains of flower relict at fruit apex

Fruit pedicel length

Fruit Pedicel width

Pedicel surface

Fusion of pedicle

Immature fruit peel color

Mature fruit peel color

Fruit peel thickness

Adherence of the fruit peel

Cracks in fruit peel

Pulp in fruit

Pulp color before maturity

Pulp color at maturity

Fruit fall from hands

Flesh texture

Persistent style

$\geq 21 \mathrm{~mm}$

$5-10 \mathrm{~mm}$
Hairless

Very partially or no

visible sign of fusion

Light green

Orange

$\leq \mathrm{mm}$
Fruit does not peel

easily

Without cracks

With pulp

White

Orange

Persistent

Peft

Predominant taste

Sweet

No seed sign of pigmentation

Two rowed

Perpendicular to the stalk Perpendicular to the

stalk

13-16

$\leq 15 \mathrm{~cm}$

Curved

Slightly ridged

Lengthily pointed

Persistent style

$\leq 10 \mathrm{~mm}$

$5-10 \mathrm{~mm}$
Hairy

Very partially or no

visible sign of fusion

Green

Bright yellow

$\leq 2 \mathrm{~mm}$

Fruit peel easily

Without cracks

With pulp

White

Cream

Deciduous

Soft

No seed

$\leq 12$

$\geq 31 \mathrm{~cm}$

Curved

Lengthily pointed

Not persistent

$\geq 21 \mathrm{~mm}$

$\geq 10 \mathrm{~mm}$

Hairless

Light green

Yellow

$>3 \mathrm{~mm}$

easily

Without cracks

With pulp

White

Ivory

Persistent

Firm

Astringent

No seed
Very development

Triangular

Yellow

White

White

No pigmentation

Curved at the base

Yellow

Arched

Green

Triangular

White

Cream

Cream

No pigmentation

Straight

Cream

Arched

White

Very few or no visible Very few or no visible

sign of pigmentation sign of pigmentation

Two rowed

Curved towards stalk

of development

Obtuse

Cream

Cream

Cream

Cream

No pigmentation

Straight

Cream

Arched

Green

Very few or no visible Very few or no visible sign of pigmentation

Two rowed

Curved upward

$\geq 17$

$16-20 \mathrm{~cm}$

$\geq 17$

Slightly ridged $\quad$ Rounded

Blunt-tipped

Rounded

Not persistent style

Bottle-necked

$<10$

$5-10 \mathrm{~mm}$

Not persistent style

$\leq 10 \mathrm{~mm}$

$5-10 \mathrm{~mm}$

Hairy

visible sign of fusion visible sign of fusion

Green

Partially fused

Green

Yellow

Light green

Fruit does not peel Fruit peel easily

\section{Cracked}

With pulp

White

Cream

Soft

Sugary

No seed
Fruit peel easily

Cracked

Without pulp

White

Yellow

Deciduous

Soft

Sweet
$\geq 20$
Little or visible of development

Transculent white Oval

the tip

Triangular

White

Yellow

Yellow

No pigmentation

Straigh

sign of pigmentation

Four rowed

Perpendicular to the

stalk

$\leq 12$

$\leq 15 \mathrm{~cm}$.

Straight in the distal part

Pronounced ridges

Blunt-tipped

Persistent style

$\geq 21 \mathrm{~mm}$

$\geq 10 \mathrm{~mm}$

Hairless

Very partially or no

visible sign of fusion

Dark green

Yellow

$3 \mathrm{~mm}$

Fruit does not peel

easily

Without cracks

Without pulp

Cream

Cream

Persistent

Firm

Astringent

$\geq 20$ 


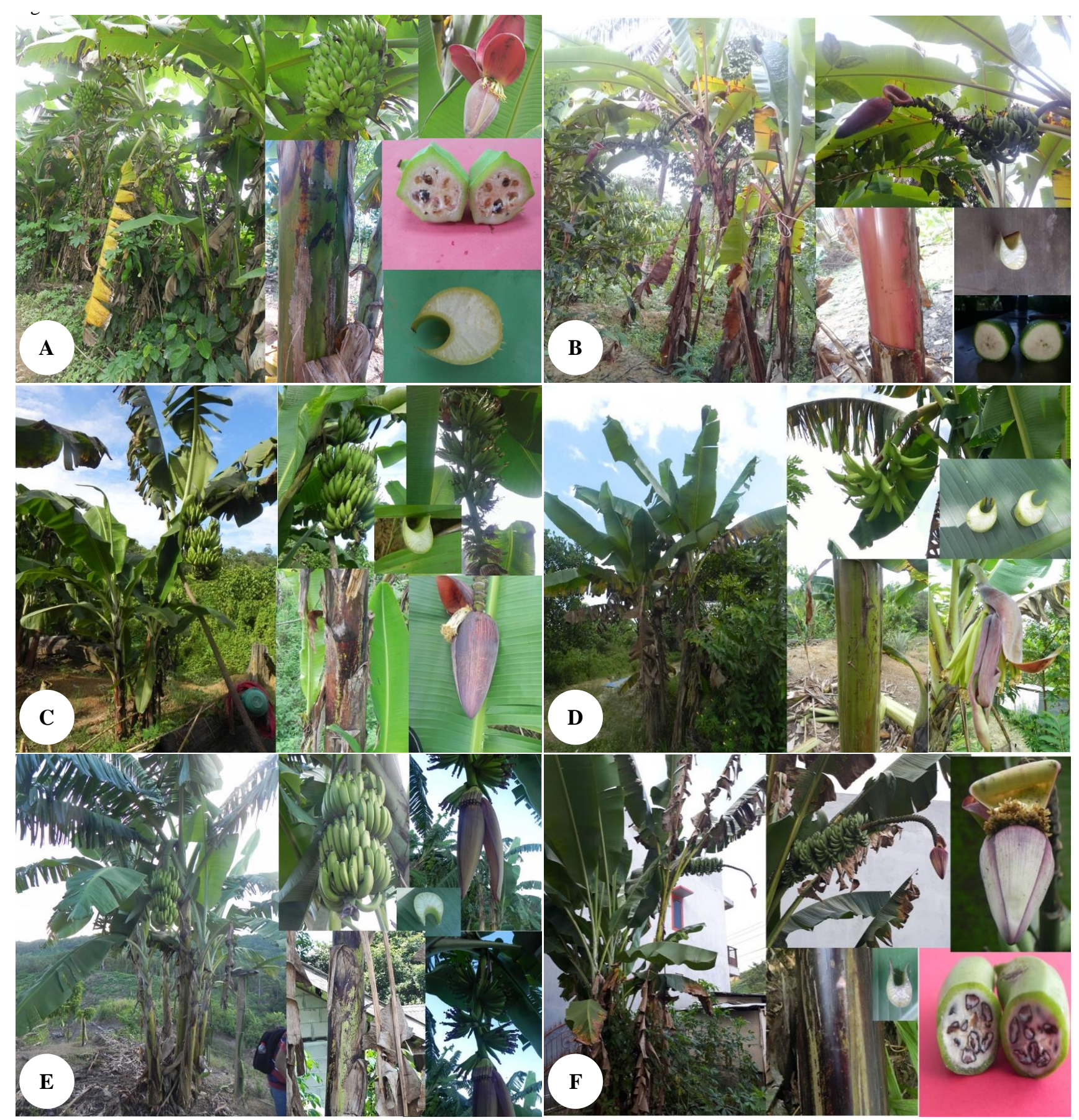

Figure 1. Morphological characters of six banana cultivars from East Kalimantan. A. Liar/monyet banana (M. acuminata), B. Klutuk banana (M. balbisiana), C. Talas banana, D. Rutai banana, E. Ambon banana, F. Tanduk banana

\section{Flower morphology and fertility status}

The flower morphology can be used as an indicator of the banana sterility determining seed production in the fruit and might be the genomic ploidy of the plants. The flower morphology and physiology are one of the factors determining the gamete sterility besides the chromosome structure such as heterozygosity and triploidy causing meiotic error during gamete cell division (Bakry et al. 2009). The fertile banana plant is shown by the seed occurrence in the fruit indicating the successful fertilization of the banana flower. Most modern bananas are seedless which have triploid genome (3n: $\mathrm{AAA}, \mathrm{AAB}, \mathrm{ABB}$, or BBB) since they are male sterile. The triploid is the optimum ploidy that can produce good agronomic performance and shows gamete sterility. The triploid banana occurs due to the crossing fertilization between the diploid banana producing $2 n$ gametes and other diploid species producing $n$ gamete (Bakry et al. 2009). The fertile bananas produce seeds in the fruit mostly derived from the diploid or tetraploid cultivars (2n: AA, BB or $4 \mathrm{n}$ : AABB, $\mathrm{BBBB}, \mathrm{AAAB}$, and $\mathrm{ABBB}$ ) although the number of seeds is varied among accessions. The fruit development of 
banana is contributed by the parthenocarpy process which allows the development of fruit without fertilization process (Dodds and Simmonds 1948). It is contributed mostly from the M. acuminata character (Simmonds 1953). The selection of cultivated banana is based on the parthenocarpy, gamete sterility, and triploidy (Simmonds and Shepherds 1955).

The flower morphology observation of liar/monyet, Ambon, rutai, talas, tanduk, and klutuk banana showed that liar/monyet and klutuk bananas are fertile of which flowers contained functional pollens (Figure 2.A and F). This indication is supported by the seed existence composing the fruit aril in the liar/monyet and klutuk banana (Figure 2.A and F). Liar/monyet banana is reported as a diploid banana which has AA genome (Retnoningsing 2009; Retnoningsing et al. 2014) and klutuk banana ( $M$. balbisiana) is a diploid banana containing BB genome (Sumardi and Wulandari 2010; Retnoningsih et al. 2014; Fitriyah et al. 2017). Therefore the production of seeds in their fruit aril is supported by the functional and fertile flowers of the diploid banana cultivars. On the contrary, the pollens of Ambon, rutai, talas, and tanduk banana flowers are absent (male sterile). These indicate that the most important organ for fertilization is not functional therefore the seeds are absent in their fruit (Figure 1.B, C, D, and E). However, the structure of anther, stigma, stylus, and tepal of Ambon, rutai and talas banana is complete and normal. The only abnormal organ was the pollen absence (Figure 2.B, C, D). Whereas, the organ structures of tanduk banana supporting the flower are abnormal, truncated, and even absent (Figure 2.E). Ambon banana has been identified as a triploid with AAA genome (Retnoningsih et al. 2014), so the male sterility is contributed by its genome ploidy (3n) resulted in the seedless fruit. The genome group classification of rutai and talas banana has not been identified yet, but from the flower morphology and seed composition in the fruit, they could be suggested as triploid bananas. The abnormal flower structure of tanduk banana might contribute to the seedless and abnormal structure of the tanduk banana fruit (Figure 1.F). The genome group classification of tanduk banana has been reported as a triploid with AAB genome (Retnoningsih et al. 2014), but it should be verified since the flower morphology is quite different (Figure 2.E), therefore the sterility could be due to the genome instability or change and might not be because of the ploidy (triploid/3n).
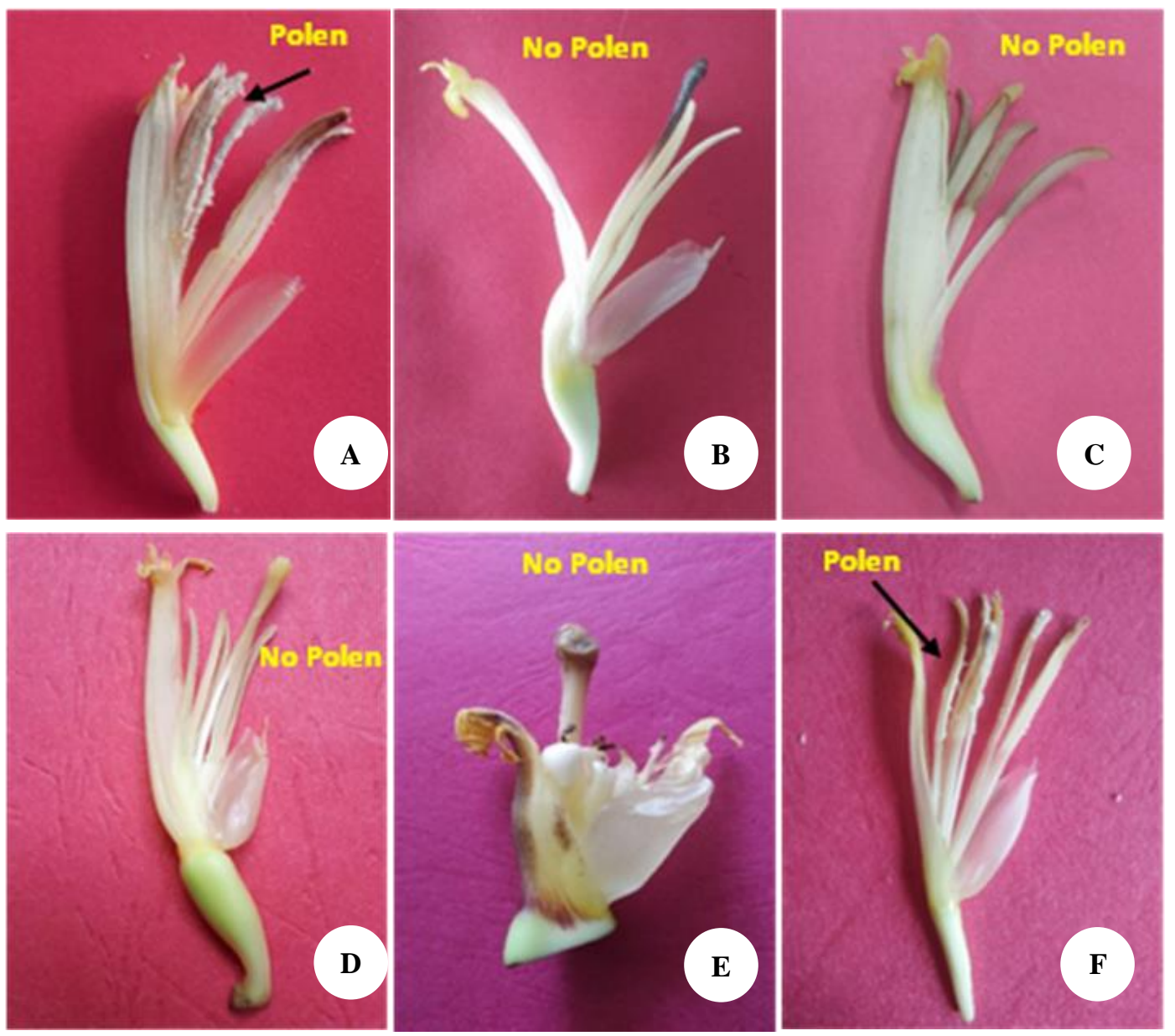

Figure 2. Flower morphology of six bananas from East Kalimantan. A. Liar/monyet banana (M. acuminata), B. Ambon banana, C. Rutai banana, D. Talas banana, E. Tanduk banana., F. Klutuk banana (M. balbisiana) 


\section{Genome classification}

The genome classification scoring of the six banana cultivars was conducted based on the Simmonds and Shepherd (1955) system using 15 key characters (Table 4). Score 1 represented the character similar to $M$. acuminata, whereas score 5 represented characters from M. balbisiana. The score 2-4 represented intermediate character between M. acuminata and M. balbisiana. The total score then was used to determine the genome group of the banana (Table 2). The genome of liar/monyet, klutuk and Ambon banana in this study confirmed the previous reports having AA, $\mathrm{BB}$, and $\mathrm{AAA}$ genome, respectively. A new records for talas and rutai banana which are grouped into AAB genome. Surprisingly, based on our observation tanduk banana is grouped into $\mathrm{AB}$ genome, which is different from the previous publications (Table 5).

Liar/monyet banana was grouped in AA genome with a score total of 15 (Table 5). This is a perfect match with $M$. acuminata characters with score 1 at all fifteen characters described (Table 4) and in line with the scoring category described in Table 2. Liar/monyet banana is most likely has AA genome, not AAA Genome, since the morphological observation showed that its fruits were fully seeded (Table 3, Figure 1.A) indicating a diploid clone. Furthermore, klutuk banana was categorized as BB genome since the total score of genome classification was 75 (Table 5) with score 5 at all fifteen key characters (Table 4) according to the genome group classification as described at Table 2 . The genome is more exactly matched with BB genotype, since it has many seeds in its fruits (Table 3, Figure 1.B). These findings are in line with the previous study that included liar/monyet banana in AA genome and klutuk banana in BB genome (Retnoningsih 2009; Retnoningsing et al. 2014; Fitriyah et al. 2017).

Ambon banana was categorized in AA/AAA genome group since the total score in the genome classification was 19 (Table 5). Although most of the key character scores were similar to those belonging $M$. acuminata, there were some characters showed score more than 1 (Table 4). From the morphological observation, Ambon banana showed strong indication as triploid genotype with the indication of seedless fruit character and flower morphology (Tabel 3, Figure 1.E, Figure 2.B), therefore it leads the conclusion that Ambon banana is a triploid banana with AAA genome as previously reported by Retnoningsih et al (2014).

Two local cultivars of banana from East Kalimantan, talas and rutai, are included into $\mathrm{AAB}$ genome group (Table 5) with the total score of 31 and 28, although the score of each key character was varied (Table 4). From the scoring, there was a strong indication that both banana cultivars belong to the AAB genome and closer to the $M$. acuminata ancestor rather than $M$. balbisiana. Talas and rutai can be used as dessert/sweet banana, but only talas banana can be used as cooking banana. The seedless fruit (Table 3) and flower morphology (Figure 2.C and D) support the triploid characters of these banana genotypes. The triploid chromosome structure, sterile gamete, and the parthenocarpy fruit development that has been revealed in these bananas are the most wanted characters for modern cultivated banana (Simmonds and shepherds 1955; Heslop-
Harrison and Schwarzacher 2007) and the goals of banana breeding (Brown et al. 2017). Since there is no previous study conducted to analyze the genome group of the talas and rutai banana, this result can be used as the first reference for sequential study using both clones. The interesting new finding was reported here that tanduk banana was classified as an amphidiploid banana with $\mathrm{AB}$ genome (Table 5). The score of each key characters in the genome classification scoring was varied and the total score was 48 (Table 4). Tanduk banana is an amphidiploid banana referring to banana containing two sets of chromosome derived from two different species. The fact that tanduk banana is an amphidiploid is supported by the unique morphology of the fruit (outward curved fruit), seedless fruit and abnormal flower morphology (Figure 1.F and 2.E). The unique morphological structure observed in amphidiploid banana was also reported in Mchare banana from Tanzania (Simmonds 1962). The existence of AB genotype is rare and some of the edible $\mathrm{AB}$ clones are found in south India, i.e., Net Poovan and Kunnan and in Papua New Guinea (De Langhe et al. 2010). The amphidiploid genome, like $\mathrm{AB}$, is usually sterile due to the mismatch chromosome pairing during meiosis resulting in an unequal chromosomal allocation at meiosis (D'Hont et al. 2000; De Langhe et al. 2010). The amphidiploid AB occurs due to the interspecific crossing between AA dan $\mathrm{BB}$ genome.

The genome classification of Indonesian bananas based on the morphological characters has been conducted for 267 accessions (Retnoningsih 2009), 20 accessions mainly from Sumatra (Rinaldi et al. 2014) and 30 accessions mainly from East Java (Fitriyah et al. 2017). The same result of genome classification between the previous studies and this current study were observed at the liar/monyet, Ambon, and klutuk banana, whereas, for the tanduk banana, the different result was found. Tanduk banana has been classified as $\mathrm{AAB}$ genotype in the previous study, but it is classified as $A B$ genotype in this study. The finding that tanduk banana is classified as $A B$ genotype will give new record for the existence of $A B$ accessions. The subsequent study is suggested using other strategies such as molecular and/or cytogenetic analysis for clarification.

\section{Diversity analysis}

The diversity analysis using morphological character was conducted to figure out the genetic relationships of talas and rutai banana with the common identified bananas, i.e., liar/monyet (M. acuminata), klutuk (M. balbisiana), Ambon and tanduk banana.

The banana accessions are grouped into two main clusters (Figure 3). The first cluster composed of the balbisiana-group which comprises of BB genotype (klutuk banana/M. balbisiana) and $\mathrm{AB}$ genotype (tanduk banana). The second cluster is acuminata-group comprising two subgroups, namely, AA/AAA and AAB genotype (Figure 3). The AA/AAA subgroup is composed of liar/monyet banana (AA genome) and Ambon banana (AAA genome). Another subgroup is AAB genotype bananas comprising talas and rutai banana. 
Table 4. Genome group scoring of six banana cultivars from East Kalimantan, Indonesia

\begin{tabular}{lcccccc} 
Character & & & & & & \\
& 2 & 3 & 4 & 2 & 1 & 5 \\
& 1 & 1 & 5 & 1 & 1 & 5 \\
\hline Pseudostem color & 2 & 2 & 5 & 2 & 1 & 5 \\
Petiole canal & 5 & 4 & 5 & 1 & 1 & 5 \\
Peduncle & 1 & 1 & 5 & 1 & 1 & 5 \\
Pedicels & 2 & 2 & 1 & 1 & 1 & 5 \\
Ovules & 1 & 1 & 4 & 1 & 1 & 5 \\
Bract shoulder & 3 & 1 & 1 & 1 & 1 & 5 \\
Bract curling & 2 & 1 & 1 & 1 & 1 & 5 \\
Bract shape & 3 & 3 & 2 & 2 & 1 & 5 \\
Bract apex & 3 & 3 & 2 & 1 & 1 & 5 \\
Bract color & 1 & 1 & 4 & 1 & 1 & 5 \\
Color fading & 1 & 1 & 1 & 1 & 1 & 5 \\
Bract scars & 2 & 1 & 4 & 2 & 1 & 5 \\
Free tepal of male flower & 2 & 3 & 4 & 1 & 1 & 5 \\
Male flower color & 31 & 28 & 48 & 19 & 15 & 75 \\
Stigma color & & & & & & \\
Total score & & & & & \\
\hline
\end{tabular}

Table 5. Genome group classification of six bananas from East Kalimantan, Indonesia

\begin{tabular}{lcc}
\hline \multicolumn{1}{c}{ Banana cultivar } & $\begin{array}{c}\text { Total } \\
\text { score }\end{array}$ & $\begin{array}{c}\text { Genome } \\
\text { classification }\end{array}$ \\
\hline Liar/monyet (Musa acuminata) & 15 & $\mathrm{AA}$ \\
Talas/sunking & 31 & $\mathrm{AAB}$ \\
Rutai & 28 & $\mathrm{AAB}$ \\
Ambon & 19 & $\mathrm{AAA}$ \\
Tanduk & 48 & $\mathrm{AB}$ \\
Klutuk (Musa balbisiana) & 75 & $\mathrm{BB}$ \\
\hline
\end{tabular}

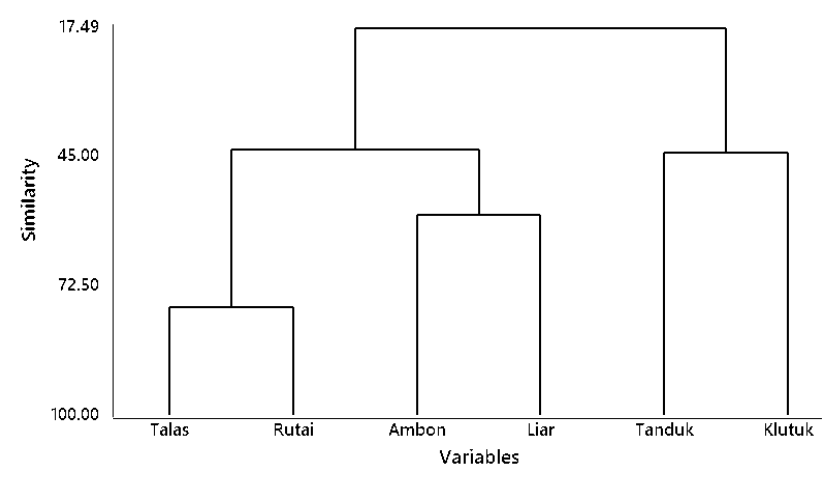

Figure 3. Dendrogram of six banana accessions from East Kalimantan, Indonesia (presented in \% of similarity)

The similarity between two main groups, i.e., acuminata-group and balbisiana-group was approximately $17.49 \%$. Furthermore, the highest level of similarity was observed between talas and rutai banana about $75 \%$, followed by Ambon and liar/monyet (about 48\%) and tanduk and klutuk (about 45\%). The results of diversity analysis were in line with the results of the genome group classification and morphological observation as previously presented (Table 1 and 5, Figure 1 and 2). The AAB genotypes (talas and rutai banana) revealed in this genome classification (Table 5) were much closely related to acuminata-type in diversity analysis. The same result was observed in AA/AAA genome accessions (Ambon and liar/monyet banana) which were also genetically close related. Furthermore, between $\mathrm{AB}$ and $\mathrm{BB}$ genotype (tanduk and klutuk banana) were clustered in the same group (Figure 3), although the similarity level was lower $(45 \%)$.

The genetic relationships and diversity among banana accessions have been extensively studied using morphological characters (Heslop-Harrison and Schwarzacher 2007; Sukartini 2007; Rinaldi et al. 2014; Fitriyah et al. 2017), RAPD markers (Kaemmer 1992; Howell et al. 1994; Jain et al. 2007), RFLP markers (Gawel and Jarret 1991; Jarret et al. 1992; Nwakanma et al. 2003; Raboin et al. 2005), SSR/ISSR markers (Creste et al. 2006; Retnoningsih 2009; Qin et al. 2011), AFLP markers (Wong et al. 2002; Noyer et al. 2005; Wongniam et al. 2010), microsatellite markers (Wahyuningtyas et al. 2009), ITS and IRAP Markers (Pachuau et al. 2014), and sequencing (Aert et al. 2004; Cheung and Town 2007; D'Hont et al. 2012; Davey et al. 2013). All genetic diversity analysis place $M$. acuminata and $M$. balbisiana in the different pool/group separated in very far genetic distance (low similarities) since they are from different species, whereas their interspecific-hybrids, referred as $M$. paradisiaca, are occupied in between of them (Espino et al. 1992 ). The existence of talas and rutai banana in the banana references will enrich genetic diversity pool of bananas contributing genetic sources for the banana breeding program and genetic improvement.

The morphological observation of around 108 characters showed that there is strong indication that characters of talas and rutai bananas are much closed related to those of belonging to $M$. acuminata although some characters showed balbisiana-type. In addition, as reported in many studies, liar/monyet and klutuk banana morphological characters represented the M. acuminata and M.balbisiana accessions. Furthermore, Ambon banana was very closely related to $M$. acuminata with the higher plants and bigger fruit but tanduk banana had a combination characters between $M$. acuminata and M.balbisiana. The genome group classification showed that talas and rutai banana are the AAB genotype, while Liar, Ambon, tanduk, and klutuk were grouped into AA, AAA, $\mathrm{AB}$, and $\mathrm{BB}$ genotypes, respectively. The classification of $\mathrm{AB}$ genome for tanduk banana was a new finding after it was reported as AAB genotype in previous studies. The diversity analysis showed that talas and rutai banana have very high similarities about $75 \%$ and closed related to AA/AAA genotype, i.e., liar/monyet and Ambon with the similarity level of $45 \%$. The similarity of acuminata-type group and balbisiana-type group in this study was around $18 \%$. 


\section{ACKNOWLEDGEMENTS}

This project was financially supported by the Hibah STRANAS for the year 2016-2018 research project, Ministry of Research, Technology and Higher Education, Republic of Indonesia. The authors are also thankful for the kind assistance and help of Lusianto and Ida for collecting some samples and specimens.

\section{REFERENCES}

Aert R, Sagi L, Volckaert G. 2004. Gene content and density in banana (Musa acuminata) as revealed by genomic sequencing of BAC clones. Theor and Appl Genet 109: 129-139.

Bakry F, Carreel F, Jenny C, Horry JP. 2009. Genetic improvement of Banana. In: Jain SM, Priyadarshan PM (eds). Breeding Plantation Tree Crops: Tropical Species. Springer Science+Business Media, Newyork.

Brown A, Tumuhimbise R, Amah D, Uwimana B, Nyine M, Mduma H, Talengera D, Karamura D, Kuriba J, Swennen R. Bananas and Plantains (Musa spp.). 2017. In: Campos H, Caligari PDS (eds). Genetic Improvement of Tropical Crops. H @ S Springer International Publishing, New York.

Cheung F, Town CD. 2007. A BAC end view of the Musa acuminata genome. BMC Plant Biol 7 (29): 1-7.

Creste S, Benatti TR, Orsi MR, Risterucci AM, Figueira A. 2006. Isolation and characterization of microsatellite loci from a commercial cultivar of Musa acuminata. Mol Ecol Notes 6: 303-306.

Crichton R, Vezina A, Van den Bergh I. 2016. An online checklist of banana cultivars. Acta Hortic 1114: 13-18.

Damayanti F. 2007. Analysis of chromosome number and stomata anatomy of several banana accessions (Musa SP.) from East Kalimantan. Bioscientiae 4 (2): 53-61. [Indonesian].

Davey MW, Gudimella R, Harikrishna JA, Sin LW, Khalid N, Keulemans J. 2013. A draft Musa balbisiana genome sequence for molecular genetics in polyploid, inter-and intra-specific Musa hybrids. BMC Genomics 14 (683): 1-20.

De Langhe E, Hribova E, Carpentier S. Dolezel J, Swennen R. 2010. Did backcrossing contribute to the origin of hybrid edible bananas? Ann Bot 106: 849-857.

D'Hont A, Paget-Goy A, Escoute J, Carreel F. 2000. The interspecific genome structure of cultivated banana Musa spp. revealed by genomic DNA in situ hybridization. Theor and Appl Genet 100: 177183 .

D'Hont A, Denoeud F, Aury JM, Baurens JC, Carreel F, Garsmeur O, Noel B, Bocs S, Droc G, Rouard M, Da Silva C, Jabbari K, Cardi C, Poulain J, Souquet M, Labadie K, Jourda C, Lengellé J, Rodier-Goud M, Alberti A, Bernard M, Correa M, Ayyampalayam S, Mckain MR, Leebens-Mack J, Burgess B, Freeling M, Mbe'guie'-A-Mbe'guie' D, Chabannes M, Wicker T, Panaud O, Barbosa J, Hribova E, HeslopHarrison P, Habas R, Ronan Rivallan1, Francois P, Poiron C, Kilia A, Burthia D, Jenny C, Bakry F, Brown S, Guignon V, Kema G, Dita M, Waalwijk C, Joseph S, Dievart A, Jaillon O, Leclercq J, Argout X, Lyons E, Almeida A, Jeridi M, Dolezel J, Roux N, Risterucci AM, Weissenbach J, Ruiz M, Glaszmann JC, Que'tier F, Yahiaoui N and Wincker P. 2012. The banana (Musa acuminata) genome and the evolution of monocotyledonous plants. Nature 488: 213-217.

Directorate General of Horticulture, Ministry of Agriculture, Republic of Indonesia. 2017. Data of Indonesia Fruit Production. http://hortikultura2.pertanian.go.id/produksi/buahan.php?page=1 . [Indonesian].

Dodds KS. Simmonds NW. 1948. Sterility and parthenocarpy in diploid hybrids of Musa. Heredity 2: 101-117.

Dolezel J, Dolezelova M, Novak FJ. 1994. Flow cytometric estimation of nuclear DNA amount in diploid bananas (Musa acuminata and M. balbisiana). Biol Plantarum 36: 351-357.

Espino RRC, Jamaludin SH, Silayoi B, Nasution RE. 1992. Musa L. (Edible banana). In: Varheij EWM, Coronel RE (eds). Asia Edible Fruits and Nuts. Plant Resources of South-East (Prosea) No. 2, Bogor, Indonesia.
Fitriyah A, Ariyanti EE, Damanhuri, Kuswanto. 2017. Grouping of 30 cultivars of banana (Musa spp.) based on genome and genetic relationships. J Produksi Pertanian 5 (4): 568-575.

Gawel NJ, Jarret RL. 1991. Chloroplast DNA restriction fragments length polymorphisms (RFLPs) in Musa species. Theor Appl Genet 81 (6): 783-786.

Heslop-Harrison JS, Schwarzacher T. 2007. Domestication, genomics and the future for banana. Ann Bot 100: 1073-1084.

Horry JP, Ortiz R, Arnaud E, Crouch JH, Ferris RSB, Jones DR, Mateo N, Picq C, Vuylsteke. 1997. Banana and plantain. In: Fuccillo D, Sears L, Stapleton P (eds). Biodiversity in Trust: Conservation and Use of Plane Genetic Resources in CGIAR Centres. Cambridge University, London.

Howell EC, Newbury HJ, Swennen RL, Withers LA, Ford-Lloyd BV. 1994. The use of RAPD for identifying and classifying Musa germplasm. Genome 37 (2): 328-332.

INIBAB. 1996. Descriptors for Banana (Musa spp.). IPGRI, Rome Italy.

INIBAP. 2000. Bananas. International Network for the Improvement of Banana and Plantain, International Plant Genetic Resources. http://bananas.biodiversityinternational.org/files/pdf/publications/broc hure-bananas.pdf

Jain PK, Saini MK, Pathak H, Gupta VK. 2007. Analysis of genetic variation in different banana (Musa species) variety using random amplified polymorphic DNAs (RAPDs). Afr J Biotechnol 6 (17): 1987-1989.

Jarret R, Gawel N, Whittemore A, Sharrock S. 1992. RFLP-based phylogeny of Musa species in Papua New Guinea. Theor Appl Genet 84 (5-6): 579-584.

Lescot T. 2011. The genetic diversity of banana in figures. Fruit Trop 189: 58-62.

Kaemmer D. 1992. Oligonucleotide and amplification fingerprinting of wild species and cultivars of banana (Musa spp.). BioTechnology 10 (9): 1030-1035.

Noyer JL, Causse S, Tomekpe K, Bouet A, Baurens FC. 2005. A new image of plantain diversity assessed by SSR, AFLP and MSAP markers. Genetica 124: 61-69.

Nwakanma DC, Pillay M, Okoli BE, Tenkouana A. 2003. Sectional relationships in the genus Musa L. inferred from the PCR-RFLP of organelle DNA sequences. Theor Appl Genet 107: 850-856.

Pachuau L, Atom AD, Thangjam R. 2014. Genome classification of Musa cultivars from Northeast India as revealed by ITS and IRAP markers. Appl Biochem Biotechnol 172: 3939-3948.

Pillay M, Tenkouano A, Hartmant J. 2002. Bananas and plantains: Future Challenges in Musa breeding. In: Crop Improvement, Challenges in the Twenty-First Century. Food Products Press, New York.

Pillay M, Tenkouano A, Ude G, Ortiz R. 2004. Molecular characterization of genomes in Musa and its applications. In: Jain SM, Swennen R (eds). Banana Improvement: Cellular, Molecular Biology, and Induced Mutations. Science Publishers Inc. Enfield, NH, USA.

Pillay M, Tripathi L. 2007. Banana. In: Kole C (ed.). Genome Mapping and Molecular Breeding in Plants Vol. 4. Fruits and Nuts. SpringerVerlag, Berlin.

Purseglove JW. 1985. Tropical Crops: Monocotyledons. Vol. 1 and 2 combined. Longman Group Limited, Essex, England.

Qin XQ, Peng HX, Long X, Yao JY. 2011. Preliminary study on ISSR analysis and classification of wild Musa germplasm in Guangxi, China. Acta Hort 897: 259-262.

Raboin LM, Carreel F, Noyer JL, Baurens FC, Horry JP, Bakry F, Tezenas Du Montcel H, Ganry J, Lanaud C, Lagoda PJL. 2005. Diploid ancestors of triploid export banana cultivars: molecular identification of $2 \mathrm{n}$ restitution gamete donors and $\mathrm{n}$ gamete donors. Mol Breeding 16: 333-341.

Retnoningsih A. 2009. Molecular based classification and phylogenetic analysis of Indonesian banana cultivars [Thesis]. Bogor Agricultural University, Bogor, Bogor. [Indonesian]

Retnoningsih A, Megia R. Hartana A. 2014. Phylogenetic relationships of Indonesian banana cultivars inferred from TrnH-F intergenic spacer of chloroplast DNA. Floribunda 4 (8): 202-211. [Indonesian].

Rinaldi R, Mansyurdin, Hermanto C. 2014. Ploidy prediction and genetic relationship of several banana accession from Balitbu Tropika Solok, Indonesia. J Sainstek 6 (1): 17-23. [Indonesian].

Setyadjit, Dimyati A, Lokollo EM, Sri Kuntarsih, Basuki RS, Hidayat A, Hofman PJ, Ledger SN, Woods EJ. 2003. In: Johnson GI, Hofman PJ (eds) Analysis of the constrains to banana industry development in Indonesia using the supply chain concept. In: Proceeding of 
International Workshop of Agri-product Supply Chain Management in Developing Countries. Canberra, ACIAR.

Silayoi B, Chomchalow N. 1987. Cytotaxonomic and morphological studies of Thai banana cultivars. In: Persley GJ, De Langhe EA (eds.). Proceedings Banana and Plantain Breeding Strategies. ACIAR Proc. 21. Canberra.

Simmonds NW. 1953. Segregations in some diploid bananas. J Genet 51: 458-469.

Simmonds NW, Shepherd K. 1955. The taxonomy and origins of the cultivated bananas. J Linn Soc London (Bot) 55: 302-312.

Simmonds NW. 1962. The evolution of the bananas. Longmans, London, UK.

Singh WR, Singh SS, Shrivastava K. 2014. Analysis of banana genome groups of wild and cultivated cultivars of Manipur, India using scorecard method. Adv Appl Sci Res 5 (1): 35-38

Stover RH. Simmonds NW, 1987. Bananas. Tropical Agricultural Series. Longman, New York.

Sukartini. 2007. Accession grouping of bananas using morphological characters from IPGRI. J Hort 17 (1): 26-33. [Indonesian]

Sumardi I, Wulandari M. 2010. Anatomy and morphology character of five Indonesian banana cultivars (Musa spp.) of different ploidy level. Biodiversitas 11 (4): 167-175.
Sunaryo W, Nurhasanah, Rahman, Sugiarto A. 2017. Identification and characterization of talas banana, a superior local cultivar from East Kalimantan (Indonesia), based on morphological and agronomical characters. Biodiversitas 18 (4): 1414-1423.

Valmayor RV, Jamaluddin SH, Silayori B, Kusomo S, Danh LD, Pascua OC, Espino RRC. 2000. Banana Cultivar Names and Synonyms in Southeast Asia. INIBAP, Asia and the Pacific Office, Philippines.

Wahyuningtyas W, Retnoningsih A, Rahayu ES. 2009. Genetic biodiversity of banana with $\mathrm{B}$ genome using microsatellite marker. Biosaintifika 1 (1): 1-10.

Wall MM. 2006. Ascorbic acid, vitamin A, and mineral composition of banana (Musa spp.) and papaya (Carica papaya) cultivars grown in Hawaii. J Food Compos Anal 19: 434-445.

Wong C, Kiew R, Argent G, Set O, Lee SK, Gan YY. 2002. Assessment of the validity of the sections in Musa (Musaceae) using AFLP. Ann Bot 90: 231-238.

Wongniam S, Somana J, Swangpol S, Seelanan T, Chareonsap P, Chadchawan S, Jenjittikul T. 2010. Genetic diversity and speciesspecific PCR-based markers from AFLP analyses of Thai bananas. Biochem Sys Ecol 38 (3): 416-427. 